\title{
Expanding access to electric vehicles in California's low-income communities
}

\section{Christopher T. Jackson}

Department of Chemistry, University of California, Berkeley, Berkeley, CA

https://doi.org/10.38126/ISPG180107

Corresponding author: ctjackson@berkeley.edu

Keywords: electric vehicle; equity; infrastructure; transportation; climate change

Executive Summary: In September 2020, California Governor Gavin Newsom announced an ambitious executive order requiring all new passenger vehicles sold in the state to be zeroemission by 2035 (California Governor 2020). This action recognizes that the growing threats of climate change and local air pollution necessitate a rapid transition away from traditional internal combustion engine vehicles. In California, disadvantaged populations in particular face significant barriers, including financing and charging, to electric vehicle (EV) adoption. For the state to meet its clean energy goals, it must include these communities in a more just transition to widespread use of EVs. This should include avenues of support such as updating state building codes for multi-unit dwellings, where almost half of all Californians live. Charging site access must be increased through curbside infrastructure expansion and institution of statewide EV charger rebates. Finally, increased access to vehicles themselves should be facilitated by expanding incentives and formats for EV sharing programs.

\section{California's EV goals}

In 2012, then-Governor Brown set the stage for California's electric vehicle industry with Executive Order B-16-2012, which set a target of 1.5 million zero-emission vehicles (ZEVs) by 2025 (California Governor 2012). This target was increased in 2018 to reach 5 million ZEVs on the roads by 2030 (California Governor 2018). Other reports have called for that target to be raised to 7.5 million in order to meet the state's climate goals (Busch and Orvis 2020). In 2020, the California Air Resources Board (CARB) passed the Advanced Clean Truck Regulation, requiring more than half of all trucks sold in the state to be zeroemissions by 2035 (Portillo 2020).

Holistically, California has made remarkable progress towards its climate goals and leads the U.S. in decarbonizing its economy (Perry et al. 2019). However, broader trends mask record highs in greenhouse gas emissions from transportation, which accounted for $41.1 \%$ of the state's total emissions in 2017 (Perry et al. 2019). Similarly, vehicle ownership and total miles driven by Californians reached all-time highs that year, likely correlated to high housing costs that push residents farther from job centers (Perry et al. 2019). Passenger vehicles are responsible for nearly a third of California's emissions, more than all the power generation, livestock, and oil refineries in the state combined (Perry et al. 2019).

While ZEVs include battery, hybrid, and hydrogenpowered vehicles, battery-powered electric vehicles (EVs) dominate the passenger vehicle market due to their lower costs. Many EVs are now commercially available and cheaper than traditional vehicles over their lifetime (Penney 2021). However, they still make up only a small fraction of all vehicles on the road, accounting for less than $10 \%$ in California (Becker 2020). Across the country, this slow adoption is driven in part by a shortage of charging infrastructure; consumers frequently cite low availability of charging stations as a barrier to buying an EV (Olson 2020; Povich 2020).

\section{The challenges of deploying EVs}

To meet the expected electricity demand that will accompany a drastic increase in EVs, California must also develop the electric charging infrastructure to power its new electric fleet (Gold 2020). While the 
state set a target of 250,000 EV charging stations by 2025 , it is unclear if it will be able to meet that goal (California Governor 2018). According to a 2017 study of charge points across ten cities (five in California) with major EV markets, significant charging gaps were expected in 2025 (Nicholas, Hall, and Lutsey 2019). The gaps are especially important given that these cities already had above-average levels of EV infrastructure compared to other cities in the U.S. in 2017.

In California, EV infrastructure development has largely been driven by legislative mandates, regulated by the California Public Utilities Commission (CPUC), and primarily carried out by investor-owned utilities. Three of California's largest utilities, Pacific Gas and Electric (PG\&E), Southern California Edison (SCE), and San Diego Gas \& Electric (SDG\&E), have pilot programs to support up to 12,500 charging stations focused on multifamily, workplace, and public markets. At least $10 \%$ are to be located in disadvantaged communities (California Public Utilities Commission n.d.). However, given the financial challenges that these utilities currently face as a result of COVID-19 and California's recent wildfires, the long-term stability of these programs is uncertain. By allowing investor-owned utilities to solely drive the growth of EV infrastructure, the state cannot guarantee a rapid and equitable development of EV infrastructure across California.

Upon closer examination, existing EV infrastructure is even less accessible for disadvantaged populations, particularly low-income communities (Song 2011). One reason for these disparities is that low-income drivers tend to live in multi-unit dwellings, where both property owners and outdated building codes create barriers against residents installing chargers (Joselow 2018). Because of this, these disadvantaged populations are often unable to take advantage of federal tax credits that incentivize EV adoption. This inability to access home charging disincentivizes EV adoption, meaning that these populations are excluded from economic benefits, such as savings over vehicle lifetime (10 years, 120,000 miles) that result from reduced fuel and maintenance costs (Malmgren 2016).

In addition to missed economic opportunities, an inequitable distribution of EVs will exacerbate significant health risks faced by disadvantaged communities (often communities of color). Studies show that communities of color are already disproportionately harmed by local vehicle air pollution (Pinto de Moura and Reichmuth 2019). Therefore, efforts towards vehicle electrification, which can significantly reduce emissions, should be concentrated in communities with higher exposure to gasoline and diesel emissions.

Enabling a just transition to electric vehicles is an opportunity for lawmakers to reverse historical trends of discrimination in the state. California's transportation sector has historically been intertwined with the marginalization of poor and minority communities. In 1944, when the Federal-Aid Highway Act allocated funds to build 1,938 miles of freeways, planners routed engineers' designs to destroy thousands of homes in racially diverse Los Angeles communities (Fleischer 2020). Policies like this mean that African Americans are about three times more likely than white residents to live in hightraffic areas and breathe harmful vehicle-related air pollution (Gunier et al. 2003).

The ramifications of these racist policies persist today as the state works towards a clean energy future. For example, California's cap-and-trade auctions, a CARB program designed to cut emissions while generating revenue for the state's Greenhouse Gas Reduction Fund, is required by law to direct 35\% of its revenues to disadvantaged communities (A.B. 1550 2016). However, studies have shown that these policies aren't doing enough to encourage uptake of solar panels and clean cars (Fournier et al. 2020). Instead, these programs disproportionately benefit wealthier homes, creating gaps in energy expenditures across race and income (Lyubich 2020; Starling 2020).

Likewise, while access to efficient transportation is the most effective predictor of escaping poverty, a growing population of younger drivers who live in cities do not own a car. This sentiment is even stronger in lower-income households, where almost $70 \%$ of those surveyed believed a car sharing service would be more economical than owning a vehicle (Zipcar 2019). Bridging the wealth gap for EV adoption and meeting the state's emissions targets will require a holistic approach that intentionally targets the longstanding marginalization and barriers to cleantech adoption that these low-income 
communities have faced in California (Citizens Utility Board 2020).

\section{Policy recommendations}

California lawmakers and state agencies can lead several measures, recommended herein, to address the aforementioned challenges and expand EV charging infrastructure in low-income communities across the state.

\section{i. Building codes}

State agencies must update California's building codes to increase standards for charging stations in multi-unit dwellings. Studies have shown that multiunit dwellings will house 120,000 plug-in electric vehicles (PEVs) by 2025, with a projected gap of $66,000-79,500$ charging stations to meet this need (Waters 2018). Currently, California requires all new multifamily dwellings, regardless of size, to implement EV charging in $10 \%$ of parking spaces (California Air Resources Board 2019). To meet projected EV charging demand for 2050, this should be increased to at least $20 \%$ within the next five years.

\section{ii. Curbside EV charging stations}

Lawmakers must work with local municipalities and utilities to expand curbside EV charging stations. There is a unique opportunity to use the existing electrical infrastructure provided by streetlights and utility poles to power curbside charging stations, a technique that has already been piloted in cities such as London and Los Angeles (Lunetta and Stainken, 2018; Lambert 2017; Berman 2019). Traditional streetlights use high-pressure sodium vapor, which is a highly inefficient lighting source. Switching to LEDs not only improves lighting and public safety, but also has been shown in San Francisco to save about 300 kWh per light per year. With the proper infrastructure, these energy savings could then be repurposed for EV charging (Bryan et al. 2008). Because street lighting is typically owned and operated by public utilities, it can be difficult for local municipalities to easily implement changes. Switching to LED lighting and installing EV chargers would likely require partnerships with local government, public utilities, and governing bodies such as the CPUC. Despite challenges, including increased installation costs, the overall savings from energy efficiency and a secondary energy market based on EV charging should make this plan economically appealing (Davies 2016).

\section{iii. EV charger rebate programs}

California must institute a statewide EV charger rebate program for residential and commercial customers in order to supplement or replace the patchwork of rebates currently available across the state. Like the Clean Vehicle Rebate Program (CVRP) that provides rebates for purchase or lease of eligible ZEVs, this program could be administered by the CARB or similar state agency ("California Clean Vehicle Rebate Project" n.d.). This program would provide financial incentives not only for homeowners, but also for businesses and owners of MUDs to install charging stations, making EV charging more broadly accessible to low-income communities. Importantly, this program should be funded upfront by the state, with funds disbursed over time to allow for point-of-sale rebates, an important consideration for middle- or lower-income customers.

\section{iv. EV sharing programs}

Finally, California lawmakers should provide funding and direct CARB to expand EV sharing programs ("Factsheets: California's Electric Vehicle Equity Incentive and Mobility Programs" 2020). To better accommodate the diverse needs of California residents, planning around EVs and charging infrastructure must reflect the rise of vehicle sharing and automated vehicles as car ownership peaks (Johnson and Walker 2016). Regional hybrid and electric car sharing projects, supported by CARB, already exist in Sacramento, Los Angeles, Santa Cruz, and the San Joaquin Valley (Moving California n.d.). This distributed model allows for communities to tailor their car sharing services based on local needs. For example, Sacramento and Los Angeles use more traditional electric cars, whereas programs in Santa Cruz and the San Joaquin Valley have opted for shuttles and passenger vans (Moving California n.d.). Increased funding at the state level will allow local municipalities to implement and expand similar programs in their communities, ensuring that EVs are accessible to residents across the entire state.

\section{Stakeholders}

Developing a robust EV charging network will be challenging and require sustained commitment and cooperation amongst the California state legislature 
and governing bodies such as the CPUC, CARB, and California Energy Commission. While the impetus for EV policy has typically come from the legislature, agencies in collaboration with the state's investorowned utilities play a key role in implementing proposed programs. Private industry, including vehicle manufacturers, have responded positively to California's long-term EV strategy, recognizing both California's significant market share and role as a national leader establishing policies that are typically adopted by other states later. With President Biden directing federal support of EV and EV charging policies, California should set an example of action that can spur not only rapid, but also equitable, deployment.

\section{Conclusion}

To ensure a just transition towards an EV future for California's low-income communities, I recommend that California work to update its building codes for multi-unit dwellings, expand curbside charging infrastructure, institute statewide EV charger rebate programs, and expand EV sharing incentives. As the state recovers from the COVID-19 pandemic, there is an opportunity to drastically reshape California's transportation sector to combat climate change while ingraining policies that promote equity.

\section{References}

A.B. 1550. "Greenhouse gases: investment plan: disadvantaged communities". September 14, 2016.

https://leginfo.legislature.ca.gov/faces/billNavCl ient.xhtml?bill id=201520160AB1550.

Becker, Rachel. "Newsom orders ban of new gas-powered cars by 2035". CalMatters. September 23, 2020. https://calmatters.org/environment/2020/09/c alifornia-ban-gasoline-powered-cars-in-2035.

Berman, Bradley. "LA adds hundreds of EV chargers to streetlights, giving renters a place to plug in". Electrek. November 13, 2019. https://electrek.co/2019/11/13/la-addshundreds-of-ev-chargers-to-streetlights-givingrenters-a-place-to-plug-in.

Bryan, Mary Matteson, Tyson Cook, Jordan Shackelford, and Terrance Pang. "LED Street Lighting. Host Site: City of San Francisco, California". Pacific Gas \& Electric. December 2008.

https://www1.eere.energy.gov/buildings/public ations/pdfs/ssl/gateway sf-streetlighting.pdf.
Beyond the transportation sector, these proposals have potential spillover benefits for other state climate goals. For example, large-scale deployment of electric vehicles could provide substantial electricity storage as back-up power systems, charging when power is abundant (i.e., at night) and in the future, potentially discharging when demand for electricity is peaking (Deaton 2020). If all of the state's proposed 5 million ZEVs by 2030 were EVs, this would represent approximately 250 million kWh of energy storage, enough to provide back-up power to all of San Francisco for about two weeks (Gorguinpour and Lashof 2019). As the state continues to deal with the effects of climate change, including threats to our electricity grid from wildfires, advances in vehicle-togrid services will make this electricity reserve invaluable.

EV deployment and infrastructure programs in California should be designed closely with local community stakeholders and public utilities responsible for service, ensuring feasible outcomes that are rooted in environmental justice.

Busch, Chris and Robbie Orvis. "Insights from the California Energy Policy Simulator". Energy Innovation. January 2020. https://energyinnovation.org/wpcontent/uploads/2020/01/Insights-from-theCalifornia-Energy-Policy-Simulator 1.16.20.pdf.

California Air Resources Board. “Appendix B: CARB's Zero-Emission Vehicle Programs". December 2019.

https://ww2.arb.ca.gov/sites/default/files/2019 -12/SB\%20498\%20Appendix $\% 20 B \% 20$ \%20ZEV\%20Programs\%20120719.pdf.

"California Clean Vehicle Rebate Project". n.d. https://cleanvehiclerebate.org/eng.

California Governor. "Executive Order B-16-2012". March 23, 2012. https://www.ca.gov/archive/gov39/2012/03/2 3/news17472/index.html.

California Governor. "Executive Order B-48-18". January 26, 2018. https://www.ca.gov/archive/gov39/2018/01/2 6/governor-brown-takes-action-to-increasezero-emission-vehicles-fund-new-climateinvestments/index.html. 
California Governor. "Executive Order N-79-20". September 23, 2020.

https://www.gov.ca.gov/wpcontent/uploads/2020/09/9.23.20-EO-N-79-20text.pdf.

California Public Utilities Commission. "Zero-Emission Vehicles". California Public Utilities Commission. n.d. https://www.cpuc.ca.gov/zev.

Citizens Utility Board. "EV for All: Electrifying Transportation in Low-Income Communities". June 2020. https://www.citizensutilityboard.org/wpcontent/uploads/2020/06/EV-for-All.pdf.

Davies, Alex. "LA's Using Energy Savings from LED Streetlights to Charge Electric Vehicles". Wired. June 8, 2016.

https://www.wired.com/2016/06/las-usingenergy-savings-led-streetlights-charge-electricvehicles.

Deaton, Jeremy. "Electric Cars Could Save California's Power Grid". Nexus Media. December 7, 2020. https://nexusmedianews.com/electric-carscould-save-californias-power-grid.

"Factsheets: California's Electric Vehicle Equity Incentive and Mobility Programs". The Greenlining Institute. May 8, 2020.

https://greenlining.org/publications/2020/facts heets-californias-electric-vehicle-equityincentive-and-mobility-programs.

Fleischer, Matthew. "Opinion: Want to tear down insidious monuments to racism and segregation? Bulldoze L.A. freeways". Los Angeles Times. June 24, 2020.

https://www.latimes.com/opinion/story/202006-24/bulldoze-la-freeways-racism-monument.

Fournier, Eric Daniel, Robert Cudd, Felicia Federico, and Stephanie Pincetl. "On energy sufficiency and the need for new policies to combat growing inequities in the residential energy sector". Elementa: Science of the Anthropocene 8 (2020). https://doi.org/10.1525/elementa.419.

Gold, Russell. "California Wants Cars to Run on Electricity. It's Going to Need a Much Bigger Grid". The Wall Street Journal. September 25, 2020. https://www.wsj.com/articles/california-wantscars-to-run-on-electricity-its-going-to-need-amuch-bigger-grid-11601036583.

Gorguinpour, Camron and Dan Lashof. "How California Can Use Electric Vehicles to Keep the Lights On". World Resources Institute. November 6, 2019. https://www.wri.org/blog/2019/11/howcalifornia-can-use-electric-vehicles-keep-lights.
Gunier, Robert B., Andrew Hertz, Julie von Behren, and Peggy Reynolds. "Traffic density in California: Socioeconomic and ethnic differences among potentially exposed children". Nature 13 (2003). https://www.nature.com/articles/7500276.

Johnson, Charlie, and Jonathan Walker. "Peak Car Ownership Report”. Rocky Mountain Institute. 2016.

https://rmi.org/insight/peak-car-ownershipreport.

Joselow, Maxine. "Electric Car Advocates Want to Expand Access to Low-Income Communities". E\&E News. June 20, 2018.

https://www.scientificamerican.com/article/elec tric-car-advocates-want-to-expand-access-tolow-income-communities.

Lambert, Fred. "London is installing electric car charging stations inside lamp posts for street charging". Electrek. November 14, 2017. https://electrek.co/2017/11/14/londonelectric-car-charging-stations-lamp-posts-street.

Lunetta, Mary, and Katherine Stainken. "AchiEVe: Model State \& Local Policies to Accelerate Electric Vehicle Adoption". Sierra Club and Plug In America. June 2018. https://www.sierraclub.org/sites/www.sierraclu b.org/files/blog/EV\%20Policy\%20Toolkit.pdf.

Lyubich, Eva. "The Race Gap in Residential Energy Expenditures". Energy Institute at Haas. June 2020.

https://haas.berkeley.edu/wpcontent/uploads/WP306.pdf.

Malmgren, Ingrid. "Quantifying the Societal Benefits of Electric Vehicles". World Electric Vehicle Journal 8 (2016). http://www.mdpi.com/20326653/8/4/996/pdf.

Moving California. "Car Sharing \& Clean Mobility Options Inventive Programs in Disadvantaged Communities". California Air Resources Board. n.d. https://ww3.arb.ca.gov/msprog/lct/carsharing.h tm.

Nicholas, Michael, Dale Hall, and Nic Lutsey. "Quantifying the electric vehicle charging infrastructure gap across U.S. markets". The International Council on Clean Transportation. January 23, 2019. https://theicct.org/publications/charging-gapUS.

Olson, Erik B. "Federal Investment in EV Charging Infrastructure for Economic Recovery, Climate, and Public Health". The Breakthrough Institute. April 2020. https://s3.us-east2.amazonaws.com/uploads.thebreakthrough.org LEV-Infrastructure-Memo.pdf. 
Penney, Veronica. "Electric Cars Are Better for the Planet - and Often Your Budget, Too". The New York Times. January 15, 2021. https://www.nytimes.com/interactive/2021/01 $\not 15 /$ climate/electric-car-cost.html.

Perry, F. Noel, Colleen Kredell, Marcia E. Perry, and Stephanie Leonard. "2019 California Green Innovation Index". Next 10. October 8, 2019. https://www.next10.org/publications/2019-gii.

Pinto de Moura, Maria Cecilia and David Reichmuth. "Inequitable Exposure to Air Pollution from Vehicles in the Northeast and Mid-Atlantic". Union of Concerned Scientists. June 21, 2019. https://www.ucsusa.org/resources/inequitableexposure-air-pollution-vehicles.

Portillo, Patricio. "California Makes History with Clean Trucks Rule". National Resources Defense Council. June 25, 2020.

https://www.nrdc.org/experts/patricioportillo/california-makes-history-clean-trucksrule.

Povich, Elaine S. "Got an Electric Car? Great! Where Do You Plug It In?". Stateline. The PEW Charitable Trusts. January 2, 2020.

https://www.pewtrusts.org/en/research-andanalysis/blogs/stateline/2020/01/02/got-anelectric-car-great-where-do-you-plug-it-in.

Song, C.C. "Electric Vehicles: Who's Left Stranded?" The Greenlining Institute. 2011.

https://greenlining.org/wpcontent/uploads/2013/02/ElectricVehiclesRepo rt.pdf.
Starling, Marlowe. "Will Florida's Investment in Electric Vehicles Pass By Poor, Minority Communities?". WUSF Public Media. July 26, 2020. https://wusfnews.wusf.usf.edu/transportation/2 020-07-26/will-floridas-investment-in-electricvehicles-pass-by-poor-minority-communities.

Waters, Dana Papke. "Electric Vehicle (EV) Charging Infrastructure: Multifamily Building Standards". California Air Resources Board. April 13, 2018. https://www.dgs.ca.gov//media/Divisions/BSC/03Rulemaking/18MonthCodeAdoption/2018Triennial-Cycle/2018-CAC-Review/Green-codeadvisory-commitee/Pt-11-HCD-618/CARB Technical Cost Analysis $31918 \mathrm{EV}$.

Zipcar. "The state of car ownership: generations across America believe sharing a vehicle provides greater value than owning one, according to new Zipcar survey". GlobeNewswire. 2019. https://www.globenewswire.com/newsrelease/2019/09/17/1916778/0/en/The-stateof-car-ownership-generations-across-Americabelieve-sharing-a-vehicle-provides-greatervalue-than-owning-one-according-to-newZipcar-survey.html.

Christopher Jackson is a PhD Candidate in chemistry at the University of California, Berkeley, where his research focuses on developing nanomaterials tools for sensing and gene delivery in biological environments. He currently serves as the president of the Science Policy Group at Berkeley and the workshops director for Engineers \& Scientists Acting Locally. He is passionate about issues related to science policy, energy and climate, immigration, and equity. 